\title{
Health belief model and the understanding of rational use of medicines
}

\author{
Putu Eka Arimbawa ${ }^{1}$, I Putu Gede Adi Purwa Hita ${ }^{2}$, Zainal Firdaus Wardhana ${ }^{3}$ \\ ${ }^{1,2}$ Clinical Pharmacy Study Program, University Bali International, Indonesia \\ ${ }^{3}$ Hospital Administration Study Program, University Bali International, Indonesia
}

\begin{abstract}
Article Info
Article history:

Received Nov 14, 2020

Revised Feb 25, 2021

Accepted Mar 5, 2021

\section{Keywords:}

Community

Health belief model

Health perception

Rational use of medicines

ABSTRACT

Community perception is an experience that causes a different understanding of treatment. Differences in people's perceptions of drug safety will affect their attitudes towards rational use of medicines (RUM). Therefore, it is necessary to do an in-depth measurement of public perceptions. The purpose of this study was to determine the relationship between community perceptions through the health belief model (HBM) with the understanding of (RUM). This study used a cross-sectional design with 97 samples in Denpasar City, Bali, Indonesia. Data collection was conducted from November 2019 to January 2020 using a questionnaire and analyzed using binary logistic tests. The results showed that perceptions based on perceived susceptibility perceived severity, health motivation, perceived benefits, and self-efficacy did not provide a significant relationship with the understanding of RUM ( $p>0.05)$. Perceived barriers provide significant results on the understanding of RUM $(\mathrm{p}<0.05)$. Health perceptions in allergy reporting and awareness of drug use based on clinical conditions and selection of alternatives increase understanding of rational drug use. The drug-taking procedure needs to be done quickly and according to the provisions to appropriately use the medication. Therefore, health workers' role is essential in providing complete services and information about drugs in health care, especially in symptomatic drugs.
\end{abstract}

This is an open access article under the CC BY-SA license.

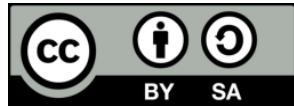

\section{Corresponding Author:}

Putu Eka Arimbawa

Clinical Pharmacy Study Program

University Bali International

Bali, Denpasar, Indonesia

Email: eka_apoteker@yahoo.co.id

\section{INTRODUCTION}

Treatment is a service provided to the community to improve health. The rational use of drugs is essential to ensure the safety of a medicine in the community. The use of drugs for health can be influenced by public perception, especially in terms of knowledge and information [1], [2]. Other research in Sungai Besar District of South also mentions that information such as advertisements can affect perceptions about drugs [3]. The results also stated that drug selection based on perception was 52.7\% [4]. The public perception itself can be measured using the health belief model (HBM) theory. This HBM theory focuses on one's subjective perceptions, such as perceived susceptibility, perceived severity, perceived benefits, health motivation, perceived barriers, and self-efficacy [5], [6]. The use of drugs in the community for healing from illness is very high. The results showed that people save drugs for self-medication by $48.1 \%$ [7]. Rational use of medicine (RUM) is a priority for the use of drugs that are following guaranteed safety quality and are available in the community [8]. Inappropriate treatment can cause problems in drug use [9]. One of them is 
the irrational use of drugs. Results several studies show that RUMs in Panyabungan and Denpasar cities are only $40.6 \%$ and $44.3 \%$ [10], [11]. Current research reveals gaps in the public's view of drug safety, consequently affecting their attitudes on RUM [12]. The results also showed that low perception and knowledge could provide unsafe medication [13]. The results of other studies about public perception do not affect drug use. Howefer, information from health professionals affects the RUM [14]. Therefore, it is necessary to do an in-depth measurement of public perceptions in influencing the RUM.

HBM is a form of description of the sociopsychological model that is used to understand individual health behaviour through beliefs and to examine how these changes [15]. This research is different from previous research, which is more explicitly exploring the perception of RUM through the HBM approach. The urgency of this research was due to a lack of understanding of RUM in the community, particularly in the city of Denpasar. The purpose of this study is to look at the relationship between community perceptions based on the health belief model (HBM) approach with an understanding of RUM.

\section{RESEARCH METHOD}

\subsection{Type of study and duration}

This study was cross-sectional survey. This study obtained an ethical clearance permit number No.001/IIK BALI/EC/XII/2019. Researchers in this study delivered questionnaire questions directly to the public. This research was conducted in January-February 2020. The sampling method was purposive sampling.

\subsection{Sample size and informant consent}

The number of sample calculations used the Levy and Lameshow formula, because the population is unknown [16].

$$
\begin{aligned}
& \mathrm{n}=\frac{\mathrm{z}_{1-\alpha}^{2} \mathrm{p}(1-\mathrm{p})}{\mathrm{d}^{2}} \\
& \mathrm{n}=\frac{\left(1.96^{2}\right) 0.5(1-0.5)}{0.1^{2}}=97 \text { Sample }
\end{aligned}
$$

where, $\mathrm{n}=$ Sample, $\mathrm{p}=$ Chance, $\mathrm{d}=$ Limit error or absolute precision, $z_{1-\alpha}^{2}=$ Trust metric

The number of samples used was 97. The study inclusion criteria were people aged 18-60 years and residing in the city of Denpasar. The exclusion criterion for this study is the community who work as health workers. Informant consent was given before filling out the questionnaire by the sample, which contained consent to the use of the sample's personal, the length of time filling out the questionnaire, benefits, inconveniences, research risks, and confidentiality of sample data. If the representative agrees it will proceed to fill out the questionnaire

\subsection{Study questionnaire and analysis}

This research was conducted quantitatively; meanwhile, the preparation of the questionnaire of quantitative and qualitative. The quantitative arrangement compares the calculated R-value with the R-Table. The qualitative interpretation was carried out using focused group design (FGD). Content validation using language experts and FGD with pharmacists. Validation and reliability tests were carried out in Badung Regency. The selection of Badung Regency is because it has similarities with the place where the research was conducted in Denpasar City compared to other districts in Bali [17].

Tool for measuring HBM variables of drug use (35 questions) using a questionnaire adapted from previous research [18]. Test the validity and reliability using 42 samples. The test results are valid-reliable with values R-Table $>0.304$ (validity) and Cronbach's Alpha >0.60 (reliability). The questionnaire of HBM are shown in Table 1, lowest validity value is 0.425 , and the reliability value is 0.78 .

The RUM understanding questionnaire (15 questions) was based on theory and FGD with pharmacists in Denpasar. The questionnaire about understanding RUM are shown in Table 2, the lowest validity value, 0.310 , with a reliability of 0.79 . Statistical analysis was in the form of sample characteristics, univariate test of HBM-understanding of RUM variables, and binary logistic test. 
Table 1. Validity and reliability HBM questionnaire

\begin{tabular}{|c|c|c|c|}
\hline \multirow[t]{2}{*}{ No } & \multirow{2}{*}{ Health belief model (HBM) } & \multicolumn{2}{|c|}{ f (42 Sample) } \\
\hline & & Validity & Reliability \\
\hline & Perceived susceptibility & & \\
\hline 1 & Use of drugs without consulting can make treatment unsafe & 0.552 & \\
\hline 2 & I use the drug without consulting the chance of allergies increases. & 0.472 & \\
\hline 3 & I use drugs without consulting, and I may become ill. & 0.674 & \\
\hline 4 & I used drugs without consultation, and my body and organs became unhealthy. & 0.669 & \\
\hline 5 & If it is not a health worker who suggests drugs, it can be dangerous & 0.529 & 0.78 \\
\hline 6 & $\begin{array}{l}\text { I do not recommend my medication to other people because it causes treatment unsafe. } \\
\text { Perceived severity }\end{array}$ & 0.425 & \\
\hline 7 & Drug allergies can harm health. & 0.481 & \\
\hline 8 & I will be stressed when thinking about drug side effects. & 0.547 & \\
\hline 9 & I am afraid to think about drug allergies without consulting. & 0.685 & \\
\hline 10 & I will have side effect problems that will continue for a long time. & 0.593 & \\
\hline 11 & If I take the drug without consulting it, it can destroy my belief about medicine. & 0.578 & \\
\hline \multirow[t]{2}{*}{12} & $\begin{array}{l}\text { If I use the wrong drug and it is not consulted, it will cause changes in my life (vision loss, } \\
\text { and hearing damage) }\end{array}$ & 0.431 & \\
\hline & Health motivation & & \\
\hline 13 & I want to find the beginning of my health problems. & 0.462 & \\
\hline 14 & Being healthy is very important. & 0.474 & \\
\hline 15 & I am looking for information to improve my health. & 0.632 & \\
\hline 16 & I learned to get information on the correct use of drugs. & 0.521 & \\
\hline 17 & I think it is essential to practice behavior and knowledge to improve health. & 0.477 & \\
\hline \multirow[t]{2}{*}{18} & I used the drug by consulting beforehand. & 0.442 & \\
\hline & Perceived benefit & & \\
\hline 19 & The use of drugs in the consultation will provide an advantage & 0.655 & \\
\hline 20 & Using the consulted drug improves healing. & 0.661 & \\
\hline 21 & the consulted drug can prevent allergies & 0.483 & \\
\hline \multirow[t]{2}{*}{22} & The drug consulted provides legal protection & 0.561 & \\
\hline & Perceived barriers & & \\
\hline 23 & To get the medicine by consultation is very difficult. & 0.496 & \\
\hline 24 & The procedure for obtaining the drug can take a long time. & 0.477 & \\
\hline 25 & Nothing can help me get medicine. & 0.462 & \\
\hline 26 & I don't have to follow procedures because taking medicine without consultation can heal. & 0.633 & \\
\hline 27 & If buying over-the-counter medicine can cure, drug consultation is not necessary. & 0.627 & \\
\hline \multirow[t]{2}{*}{28} & I don't have time to get the medication in consultation. & 0.454 & \\
\hline & Self-efficacy & & \\
\hline 29 & I know the procedure for getting medicine by having a prior consultation. & 0.670 & \\
\hline 30 & I can use medicine properly. & 0.566 & \\
\hline 31 & I was able to recover because of the use of the right medicine. & 0.543 & \\
\hline 32 & I can understand the drug information provided & 0.468 & \\
\hline 33 & I was able to get the necessary information because I wanted to know the drug's proper use. & 0.591 & \\
\hline 34 & I can use the dosage of medicine properly. & 0.481 & \\
\hline 35 & I understand the timing of taking the right medication & 0.673 & \\
\hline
\end{tabular}

Table 2. Validity and reliability RUM

\begin{tabular}{llc}
\hline No & \multicolumn{1}{c}{ RUM understanding (15 item) } & $\begin{array}{c}\text { n (42 respondents) } \\
\text { Validity }\end{array}$ \\
Reliability
\end{tabular}




\section{RESULTS AND DISCUSSION}

\subsection{Sample socio-demographic characteristics}

Sample socio-demographic characteristics are shown in Table 3. A total of $63.5 \%$ of the community were female $53.6 \%$ and male $60.8 \%$ were married and $39.2 \%$ single. Among the patients, $62.9 \%$ had achieved ES/JHS/SHS (elementary/ junior high/senior school) and $37.1 \%$ university education. In terms of employment, $10.3 \%$ were unemployed, $63.9 \%$ private employees, $17.5 \%$ entrepreneurs, and $8.2 \%$ civil servant. The percentage of community with ages (years), $32 \%$ were $18-25,30.9 \% 26-35,23.7 \% 36-45$, and $13.4 \%$ 46-55, respectively

Table 3. Samples characteristics

\begin{tabular}{lcc}
\hline Sample socio-demographic characteristics & $\mathrm{n}$ (97 respondents) & $\%$ \\
\hline Gender & & \\
$\quad$ Female & 52 & 53.6 \\
$\quad$ Male & 45 & 46.4 \\
Marital status & & \\
$\quad$ Single & 38 & 39.2 \\
$\quad$ Married & 59 & 60.8 \\
Education & & \\
$\quad$ ES/JHS/SHS & 61 & 62.9 \\
$\quad$ University & 36 & 37.1 \\
Profession & & \\
Unemployed & 10 & 10.3 \\
Private employees & 62 & 63.9 \\
Entrepreneurs & 17 & 17.5 \\
$\quad$ Civil servants & 8 & 8.2 \\
Age (years) & & \\
18-25 & 31 & 32.0 \\
26-35 & 30 & 30.9 \\
36-45 & 23 & 23.7 \\
46-55 & 13 & 13.4 \\
\hline
\end{tabular}

\subsection{Test univariate HBM}

The results of Table 4 about the univariate test of the HBM approach and the understanding of RUM show that the percentage of community perceptions about perceived susceptibility being good was $51.5 \%$ and not good $48.5 \%$. The percentage of community perceptions about perceived severity being good was $54.6 \%$ and not good $45.4 \%$. The percentage of community perceptions about health motivation being good was $52.6 \%$ and not good $47.4 \%$. The percentage of community perceptions about perceived benefits being good was $63.9 \%$ and not good $36.1 \%$. The percentage of community perceptions about perceived barriers being good was $51.5 \%$ and not good $48.5 \%$. The percentage of community perceptions about self efficacy being good was $68 \%$ and not good $32 \%$.

Table 4. Univariate test of HBM

\begin{tabular}{lcc}
\hline Heathy belief model (HBM) & $\mathrm{n}$ & $\%$ \\
\hline Perceived susceptibility (median) & & \\
$\quad$ Not good & 47 & 48.5 \\
$\quad$ Good & 50 & 51.5 \\
Perceived severity (median) & & \\
$\quad$ Not good & 44 & 45.4 \\
$\quad$ Good & 53 & 54.6 \\
Health motivation (median) & & \\
$\quad$ Not good & 46 & 47.4 \\
$\quad$ Good & 51 & 52.6 \\
Perceived benefits (median) & & \\
$\quad$ Not good & 35 & 36.1 \\
$\quad$ Good & 62 & 63.9 \\
Perceived barriers (median) & & \\
$\quad$ Not good & 47 & 48.5 \\
$\quad$ Good & 50 & 51.5 \\
Self-efficacy (median) & & \\
$\quad$ Not good & 31 & 32 \\
$\quad$ Good & 66 & 68 \\
\hline
\end{tabular}




\subsection{The value of the RUM understanding questionnaire}

The results of the RUM understanding questionnaire are shown in Table 5. Most people understand the use of drugs must adjust to the patient's condition (93.8\%), and patients will not keep their drug allergies secret (90.7). The wrong value of understanding RUM in the community regarding cough, fever, and diarrhea medicine does not need to be taken until it runs out if the symptoms have disappeared $(50.5 \%)$ and all medicines taken after eating (26.8\%). The people of Denpasar City do not know about RUM's understanding of generic-patent drugs having the same effect even though the price is the highest $(30.9 \%)$.

Table 5. Results of the RUM understanding questionnaire

\begin{tabular}{|c|c|c|c|c|}
\hline \multirow{2}{*}{\multicolumn{2}{|c|}{ RUM understanding }} & \multicolumn{3}{|c|}{$\mathrm{n}(\%)$} \\
\hline & & No & Do not know & Yes \\
\hline 1 & $\begin{array}{l}\text { Do you need to consult with other diseases before you choose a } \\
\text { medication (heart disease, and diabetes) }\end{array}$ & $5(5.2)$ & $8(8.2)$ & $84(86.6)^{*}$ \\
\hline 2 & $\begin{array}{l}\text { Drug selection must be adjusted to the patient's condition (pregnant, } \\
\text { breastfeeding, and age) }\end{array}$ & $1(1)$ & $5(5.2)$ & $91(93.8) *$ \\
\hline 3 & Drug indications are the uses of a drug & $5(5.2)$ & $13(13.4)$ & $79(81.4)^{*}$ \\
\hline 4 & If I have a drug allergy, I will keep it a secret & $88(90.7)^{*}$ & $8(4.1)$ & $5(5.2)$ \\
\hline 5 & I give them information on the use of other drugs before buying & $5(5.2)$ & $13(13.4)$ & $79(81.4) *$ \\
\hline 6 & All drugs should be taken after eating & $52(53.6)^{*}$ & $19(19.6)$ & $26(26.8)$ \\
\hline 7 & Drugs taken $3 \times 1$ tablet must be drinking every eight hours & $14(14.4)$ & $23(23.7)$ & $60(61.9)^{*}$ \\
\hline 8 & Antibiotic drugs can be kept if the symptoms of the disease are gone & $57(58.8)^{*}$ & $26(26.8)$ & $14(14.4)$ \\
\hline 9 & The dose of the drug is the same as taken by each person & $80(82.5)^{*}$ & $14(14.4)$ & $3(3.1)$ \\
\hline 10 & Antibiotics can be used to treat viral infections & $66(68)^{*}$ & $20(20.6)$ & $11(11.3)$ \\
\hline 11 & $\begin{array}{l}\text { Drugs that have the same ingredients and different prices give the } \\
\text { different effects }\end{array}$ & $33(34)^{*}$ & $26(26.8)$ & $38(39.2)$ \\
\hline 12 & $\begin{array}{l}\text { Cough, fever, and diarrhea medicine does not need to be drunk until } \\
\text { it runs out if the symptoms have disappeared }\end{array}$ & $49(50.5)$ & $13(13.4)$ & $35(36.1)^{*}$ \\
\hline 13 & $\begin{array}{l}\text { The amount of medicine purchased matches with the time of takes the } \\
\text { medicine }\end{array}$ & $17(17.5)$ & 11(28.9) & $52(53.6)^{*}$ \\
\hline 14 & $\begin{array}{l}\text { Generic drugs have the same effect as patent medicines, even though } \\
\text { the price is different }\end{array}$ & $18(18.6)$ & $30(30.9)$ & $49(50.5)^{*}$ \\
\hline 15 & $\begin{array}{l}\text { I will be choosing a generic drug that cheaper than a patent medicine } \\
\text { if the money is not enough to buy a patent medicine }\end{array}$ & $14(14.4)$ & $13(13.4)$ & $75(77.3)^{*}$ \\
\hline
\end{tabular}

\subsection{The value of the RUM understanding questionnaire}

The results of the binary logistic test analysis are shown in Table 6. The sample characteristics of gender, occupation, education, marital status, and age did not provide a significant relationship to the understanding of RUM ( $p>0.05$ ). Perception value based on HBM perceived susceptibility perceived severity, health motivation perceived benefits, and self-efficacy did not provide a significant relationship with an understanding of RUM ( $p>0.05)$. Perceived barriers gave significant results on the understanding of RUM $(p<0.05)$.

Table 6. Binary logistic test

\begin{tabular}{lcccc}
\hline $\begin{array}{c}\text { Characteristics and community } \\
\text { perceptions based on HBM }\end{array}$ & OR & Lower limit & Upper limit & $\mathrm{p}$ \\
\hline Gender & 1.20 & 0.49 & 2.93 & 0.69 \\
Profession & 1.43 & 0.81 & 2.54 & 0.21 \\
Education & 0.62 & 0.24 & 1.57 & 0.31 \\
Marital status & 1.01 & 0.29 & 3.45 & 0.98 \\
Age & 1.15 & 0.74 & 1.78 & 0.51 \\
Perceived susceptibility & 1.40 & 0.53 & 3.68 & 0.49 \\
Perceived severity & 0.55 & 0.18 & 1.68 & 0.29 \\
Health motivation & 1.42 & 0.55 & 3.63 & 0.46 \\
Perceived benefits & 0.67 & 0.24 & 1.83 & 0.44 \\
Perceived barriers & 0.41 & 0.18 & 0.93 & 0.03 \\
Self-efficacy & 1.74 & 0.71 & 4.26 & 0.22 \\
\hline
\end{tabular}

\subsection{Discussion}

The results of the study perceived susceptibility, did not provide a significant relationship with an understanding of RUM. These results differ from studies of perceived susceptibility with values that can less influence patient involvement in understanding drug use [19]. Other studies also mention the perceived susceptibility to influence factors related to the drug selection process, including physiological status [20]. This study indicates that the community does not agree to use drugs without consultation because it can increase the risk of death [21]. The results of this perceived severity research are supported by studies that 
show the influence of drug use is not enough to motivate healthy perceptions in drug use [22]. Other studies have had different results regarding patients' perceptions of reasonable safety risks that can improve healthy behavior [23]. Other research also mentions that the use of appropriate drugs is a useful step towards healthy behavior in the community [24]. This difference in results is because the incidence of drug allergy is rare. Therefore, people still do not show the perceived severity of drug use, howefer the community has already reported allergies to health workers, increasing awareness of drug understanding.

Health motivation has inconsistent results with the use of drugs, especially in the treatment of chronic diseases [25]. The results of other studies also support many decisions not influenced by health motivation; drug use is not always planned and is strongly influenced by emotional factors [26]. This is contrary to health motivation research regarding certain aspects of treatment as crucial for changing health behavior [27]. This is because the statement of the public being healthy with drugs is less critical. This is supported by the results of public understanding of RUM regarding drug selection is strongly influenced by clinical conditions, and will use other alternatives if the use of drugs is detrimental. Perceived benefit does not affect the understanding of RUM. This contradicts research, which states that perceived benefits increase motivation for treatment behavior [28]. The research data states that public perceptions of using drugs do not need consideration from pharmacists, howefer rather to the administration of obtaining drugs. This is consistent with research that states that rational drug use is influenced by access to health facilities, regulation of the drug dispensing process, and regulation [5]. This study's results have a similar value and are in line with research that states perceived benefits (64\%) [29]. There are still many mistakes in using rational medicine for symptomatic drugs that are taken until they run out. This is because people feel that taking medicine until it runs out will provide benefits to be healthier.

The results of self-efficacy research did not provide a significant relationship to the understanding of RUM. This contradicts research, which states the use of self-efficacy is related to the scale of the right drug use [30]. This difference in results is due to people's perceptions of not agreeing with the important procedures of obtaining drugs, so that understanding of RUM many errors in symptomatic treatment and the effects of generic-patent medicines. The results of the perceived barrier study with the understanding of RUM show significant results. This result is different from research, which states that the perceived barrier does not affect a person's desire to use drugs and is more influenced by culture [31]. The findings of this study are confirmed by other studies that show the community 's willingness to use anything suitable because of the lack of access to knowledge and time and insufficient public access to health services [32]. This is also consistent with the research data of public perceptions that strongly agree on the limited time to obtain drugs and affect the understanding of RUM, especially in information on symptomatic treatment.

\section{CONCLUSION}

Health perceptions in allergy reporting and awareness of drug use based on clinical conditions and selection of alternatives increase understanding of rational drug use. The drug-taking procedure needs to be done quickly and according to the provisions to appropriately use the medication. Therefore, health workers' role is essential in providing complete services and information about drugs in health care, especially in symptomatic drugs.

\section{REFERENCES}

[1] F. Morison, E. K. Untari and I. Fajriaty, "Analysis of the level of knowledge and perceptions of the people of the city of Singkawang towards generic drugs/Analisis tingkat pengetahuan dan persepsi masyarakat kota singkawang terhadap obat generik," Jurnal Farmasi Klinik Indonesia, vol. 4, no. 1, pp. 39-48, 2015.

[2] C. M. Sihombing, I. Efendy, and A. J. Hadi, "Factors Affecting the Behavior of Food Providers Against The Implementation of Clean And Healthy Living Behavior In Panyabungan Cipto District Stalls/Faktor Yang Mempengaruhi Perilaku Penyedia Makanan Terhadap Pelaksanaan Perilaku Hidup Bersih Dan Sehat Di Warung Kecamatan Panyabungan Cipto, ” Window of Health Jurnal Kesehatan, vol. 3, no. 1, pp. 18-27, 2020.

[3] S. Adawiyah, N. Cahaya, and D.Intannia, "The relationship between perceptions of laxative drug advertisements on television with community self-medication in Sungai Besar Village, Banjarbaru District/Hubungan persepsi terhadap iklan obat laksatif di televisi dengan perilaku swamedikasi masyarakat di Kelurahan Sungai Besar Kecamatan Banjarbaru," Journal of Pharmaceutical, vol. 14, no. 1, pp. 108-126, 2017.

[4] Marwati and Amidi, "The influence of culture, perceptions, and beliefs on herbal medicine purchasing decisions IPengaruh budaya, persepsi, dan kepercayaan terhadap keputusan pembelian obat herbal," Jurnal Ilmu Manajemen, vol. 7, no. 2, pp. 168-180, 2018.

[5] A. N. Insany, D. P. Destiani, A. Sani, L. Sabdaningtyas, and I. S. Pradipta, "Perceptions Relationship to Antibiotic Medication Behavior: Observational Study through the Theory of Health Belief Model Approach/Hubungan Persepsi terhadap Perilaku Swamedikasi Antibiotik: Studi Observasional melalui Pendekatan Teori Health Belief Model," Jurnal Farmasi Klinik. Indonesia, vol. 4, no. 2, pp. 77-86, 2015. 
[6] Z. Yue, C. Li, Q. Weilin, and W. Bin, "Patient Education and Counseling Application of the health belief model to improve the understanding of antihypertensive medication adherence among Chinese patients," Patient Education and Counseling, vol. 98, no. 5, pp. 669-673, 2015.

[7] L. Khairiyati, "Factors related to storage of hard drugs and antibiotics without prescription in Gorontalo Province/Faktor yang berhubungan dengan penyimpanan obat keras dan obat antibiotika tanpa resep di Provinsi Gorontalo," Jurnal Publikasi Kesehatan. Masyarakat. Indonesia, vol. 2, no. 1, pp. 13-19, 2015.

[8] P. E. Arimbawa and I. P. G. P. Adi, "Patient perceptions on the role of a pharmacist and the understanding of the rational use of medicines (RUM)," Journal of Sustainability Science and Management, vol. 14, no. 6, pp. 137-144, 2019.

[9] L. Gökçekuş, A. Mestrovic, and B. Basgut, "Pharmacist intervention in drug-related problems for patients with cardiovascular diseases in selected community pharmacies in Northern Cyprus," Tropical Journal of Pharmaceutical Research, vol. 15, no. 10, pp. 2275-2281, 2016.

[10] N. A. Harahap, K. Khairunnisa, and J. Tanuwijaya, "Patient knowledge and rationality of self-medication in three pharmacies of Panyabungan City, Indonesia," Jurnal Sains Farmasi \& Klinis, vol. 3, no. 2, pp. 186-192, 2017.

[11] P. E. Arimbawa, "The relationship between health insurance ownership and rational drug use (POR) in selfmedicated patients/Hubungan kepemilikan asuransi kesehatan dengan penggunaan obat rasional (POR) pada pasien swamedikasi," Medicamento, vol. 4, no. 2, pp. 118-122, 2017.

[12] D. Alkhalidi, S. Q. Jamshed, R. M. Elkalmi, M. R. Baig, A. Aslam, and M. A. Hassali, "General Public Views, Attitudes, and Experiences toward Drug Safety in Dubai, United Arab Emirates: A Qualitative Approach," Pharmacy, vol. 7, no. 1, p. 19, 2019.

[13] Syofyan, H. D. Ghiffari, and Erizal Zaini, "Perceptions, knowledge, and attitudes about medicine among high school students (SMA) in Kota Pariaman, West Sumatra,” Jurnal Sains Farmasi and Klinis, vol. 4, no. 1, pp. 83-87, 2017.

[14] N. F. Basaran and A. Akici, "Patients' experience and perspectives on the rational use of drugs in Turkey: A survey study," Patient Prefer Adherence, vol. 6, pp. 719-724, 2012.

[15] W. J. Rejeski and J. Fanning, "Models and theories of health behavior and clinical interventions in aging: A contemporary, integrative approach," Clinical Interventions in Aging, vol. 14, pp. 1007-1019, 2019.

[16] Levy and Lameshow, "Sampling of Populations: Methods and Applications," John Wiley and Sons, 2008.

[17] P. I. P. Putra and I. P. Yadnya, "Analysis of Economic Leading Sectors in Denpasar, Badung, Gianyar, and Tabanan Regencies/Cities/Analisis Sektor Unggulan Perekonomian di Kabupaten/Kota Denpasar, Badung, Gianyar, dan Tabanan," E-Jurnal Manajemen Unud, vol. 7, no. 10, pp. 5657-5685, 2018.

[18] B. Erci and Zeynep Çiçek, "Reliability and Validity of Drugs Use Health Belief Scale in Adult Women," International Archives of Nursing and Health Care, vol. 3, no. 1, pp. 1-7, 2017.

[19] C. Heid, M. J. Knobloch, L. T. Schulz, S. M. Memorial, and V. Hospital, "Use of the health belief model to study patient perceptions of antimicrobial stewardship in the acute care setting," Infection Control and Hospital Epidemiology, vol. 37, no. 5, pp. 576-582, 2017.

[20] R. Ofori-Asenso and A. A. Agyeman, "Irrational Use of Medicines- A Summary of Key Concepts," Pharmacy, vol. 28, no. 4, p. 35, 2016.

[21] R. M. Thaha, N. Baharuddin, and M. Syafar, "Abuse of Hard Drugs by Construction Workers in the Parangloe Indah Warehouse, Makassar City /Penyalahgunaan Obat Keras Oleh Buruh Bangunan Di Pergudangan Parangloe Indah Kota Makassar," Jurnal MKMI, vol. 12, no. 2, pp. 118-126, 2016.

[22] S. R. Jaberee, T. Aghamolaei, and L. Hassani, "Adopting Self-Medication Prevention Behaviors According to Health Belief Model Constructs," hormozgan medical journal, vol. 24, pp. 1-6, 2020.

[23] A. C. Bishop, G. R. Baker, T. A. Boyle, and N. J. Mackinnon, "Using the health belief model to explain patient involvement in patient safety," Health Expectations, vol. 18, no. 6, pp. 3019-3033, 2015.

[24] Z. S. Motavali, H. Abedi, E. Davaridolatabadi, and Y. Researchers, "Self-medication and its Effective Modifiable Factors among Elderly Referred Health Care Centers in Shahr-e-Kord in 2015," Electronic Physician Journal, vol. 8, no. 11, pp. 3205-3213, 2016.

[25] A. Palacio, D. Garay, B. Langer, J. Taylor, B. A. Wood, and L. Tamariz, "Motivational Interviewing Improves Medication Adherence: a Systematic Review and Meta-analysis," Journal of General Internal Medicine, vol. 8, pp. 929-940, 2015.

[26] P. W. Corrigan, N. Rüsch, and T. Sher, "Adherence in People with Psychiatric Disabilities," Rehabilitation Psychology, vol. 59, pp. 85-98, 2015.

[27] C. Sandlund, K. Kane, M. Ekstedt, and J. Westman, "Patients' experiences of motivation, change, and challenges in group treatment for insomnia in primary care : a focus group study," BMC Family Practice, vol. 19, no. 1, p. 111, 2018

[28] P. Shabibi et al., "Effect of educational intervention based on the Health Belief Model on promoting self-care behaviors of type-2 diabetes patients," Electronic Physician Journal, vol. 9, no. 12, pp. 5960-5968, 2017.

[29] F. Ilika, M. Jamshidimanesh, M. Hoseini, M. Saffari, and H. Peyravi, "An evaluation of high-risk behaviors among female drug users based on Health Belief Model," Journal of Medicine and Life, vol. 8, no. 3, pp. 36-43, 2015.

[30] D. Mangin, "Self-efficacy for Medication Management: A Systematic Review of Instruments," Patient Preference and Adherence, vol. 12, pp. 1279-1287, 2018.

[31] P. E. Arimbawa and N. P. A. Suryaningsih, "Relationship of perception Of self-medication behavior use of complementary alternative medicine (CAM) in Denpasar City (observational study through theory approach drug use health belief model)," Indian Journal of Pharmaceutical Sciences, vol. 6, no. 2, pp. 1845-1851, 2019.

[32] M. Baig, Z. Sayedalamin, O. Almouteri, M. Algarni, and H. Allam, "Perceptions, perceived barriers and practices of physicians' towards Evidence-Based Medicine," Pakistan Journal of Medical Sciences, vol. 32, no. 1, pp. 49-54, 2016. 